\title{
Changes in phytoplankton composition in response to tides, wind-induced mixing conditions, and freshwater outflows in an urbanised estuarine complex
}

\author{
Moser GAO. ${ }^{a *}$, Ciotti AM. ${ }^{b}$, Giannini MFC. ${ }^{b}$, Tonini RT. ${ }^{b}$ and Harari J. ${ }^{c}$ \\ áFaculdade de Oceanografia, Universidade do Estado do Rio de Janeiro - UERJ, \\ Rua São Francisco Xavier, 534, CEP 20550-103, Rio de Janeiro, RJ, Brazil \\ 'Universidade Estadual Paulista Júlio de Mesquita Filho - UNESP, \\ Praça Infante Don Henrique, s/n, CEP 11330-900, São Vicente, SP, Brazil \\ 'Instituto Oceanográfico - IO, Universidade de São Paulo - USP, \\ Praça do Oceanográfico, 191, Cidade Universitária, CEP 05508-120, São Paulo, SP, Brazil \\ *e-mail: gleyci_moser@uerj.br
}

Received December 24, 2010 - Accepted March 14, 2011 - Distributed February 29, 2012

(With 5 figures)

\begin{abstract}
Recent reports have shown an increase in potentially harmful phytoplankton in Santos bay (Southeastern Brazilian Coast), located in a highly urbanised estuarine complex. Prediction of blooms is, thus, essential but the phytoplankton community structure in very dynamic regions is difficult to determine. In the present work, we discriminate bloom forming microphytoplankton dominance and their relationship to physical and meteorological variables to look for patterns observed in different tides and seasons. Comparing 8 distinct situations, we found five scenarios of dominance that could be related to winds, tides and rainfall: i) Surfers, diatoms occurring during high surf zone energies; ii) Sinkers, represented by larger celled diatoms during spring tide, after periods of high precipitation rates; iii) Opportunistic mixers, composed of chain forming diatoms with small or elongate cells occurring during neap tides; iv) Local mixers, microplanktonic diatoms and dinoflagellates which occurred throughout the 298 sampling stations; and v) Mixotrophic dinoflagellates, after intense estuarine discharges. Results suggest alterations in the temporal patterns for some bloom-forming species, while others appeared in abundances above safe limits for public health. This approach can also illustrate possible impacts of changes in freshwater discharge in highly urbanised estuaries.
\end{abstract}

Keywords: phytoplankton composition, winds, tides, Santos bay, rainfall.

\section{Variações na composição da comunidade fitoplanctônica em resposta às marés, à mistura induzida pelo vento e à descarga de água doce em um sistema estuarino urbanizado}

\begin{abstract}
Resumo
Estudos recentes na baía de Santos (sudeste do Brasil), localizada em um sistema estuarino altamente urbanizado, mostraram o aumento de espécies fitoplanctônicas potencialmente nocivas. Apesar da importância da previsão das florações algais nocivas, é difícil determinar a estrutura da comunidade fitoplanctônica em ambientes extremamente dinâmicos. O presente estudo analisa florações dominadas pelo microfitoplâncton e sua relação com variáveis físicas e meteorológicas, a fim de determinar padrões associados às marés e às estações do ano. Foram comparadas oito situações e obtidos cinco cenários de dominância relacionados aos ventos, marés e pluviosidade: i) Surfers, diatomáceas associadas à zona de surfe, de alta energia; ii) Sinkers, diatomáceas de tamanho grande que ocorrem nas marés de sizígia, depois de períodos de alta pluviosidade; iii) Opportunistic mixers, diatomáceas pequenas ou alongadas, formadoras de cadeia, que ocorrem durante períodos de quadratura; iv) Local mixers, diatomáceas e dinoflagelados microplanctônicos que foram abundantes em todas as 298 estações amostradas, e v) Mixotrophic dinoflagellates, que ocorrem após intensas descargas estuarinas. Os resultados sugerem uma alteração no padrão temporal de algumas espécies formadoras de florações, enquanto outras apresentaram abundâncias superiores aos valores seguros para a saúde publica. Esta abordagem ilustra também os possíveis impactos de variações na descarga de água doce em estuários altamente eutrofizados.
\end{abstract}

Palavras-chave: composição do fitoplancton, ventos, marés, baía de Santos, pluviometria. 


\section{Introduction}

Understanding how changes in environmental conditions are capable of driving phytoplankton dominance is key for comprehending coastal dynamics and to develop environmental monitoring programmes. Changes in phytoplankton taxonomic composition, in a given time and place, are well documented and are manifestations of the adaptive strategies and modes of nutrition of occurring species (e.g. Margalef, 1997). In shallow estuaries, short-term and transient gradients of river outflows (Acha et al., 2008), tide regimes, vertical mixing and turbidity (Baek et al. 2008), and nutrient inputs (Heil et al. 2005; Glibert et al., 2006), especially in areas with intense human occupation, hamper the attempts for structure determination of phytoplankton communities, either taxonomic or as functional groups. Human induced eutrophisation can trigger harmful algal blooms, so the development of conceptual models for phytoplankton dominance is imperative (Cloern, 1996). Furthermore, environmental policies demand quantitative assessments of variables altered by increasing urbanisation and their potential relationships to bloom-forming phytoplankton growth conditions (Whitea et al., 2004; Burkholder et al., 2006).

The relationships between increase in both input and residence times of anthropogenic nutrients in estuarine systems and enhancements of phytoplankton biomass are well documented (e.g., Pinckney et al., 2001). Studies in costal regions, influenced by estuaries, show that inputs of nutrients drive changes on the frequency of local algal blooms (Glibert et al., 2006), with occasional changes in taxa that may even include potential harmful species (harmful algal blooms- HABs - Hallegraeff, 2004; Zingone and Enevoldsen, 2000; Heil et al., 2005), but in many regions of the coastal oceans, the available information is not enough to link the occurrence of HABs and anthropogenic effects (Anderson, 2008).

Highly urbanised coastal areas are influenced by domestic and industrial sewage, often mixed with pollutants and a range of dissolved and particulate materials and the effects of these mixtures on phytoplankton composition are still little understood (Thomas et al., 1980; Walter et al., 2002). Anthropogenic activities in coastal areas can alter the overall freshwater inputs to estuaries (Paerl et al., 1998) as well, which may drive additional changes of phytoplankton community structure (Kimmerer, 2002; Hallegraeff, 2004).

The Estuarine complex of Santos (SE Brazil) (Figure 1) receives pollutants from petrochemical and fertiliser plants (Braga et al., 2000) and high concentrations of nutrients and organic matter (Moser et al., 2004; Aguiar and Braga, 2007). The literature shows high ammonium, phosphate and chlorophyll concentrations in the Santos estuarine complex year round (Gianesella et al., 2000; Aguiar and Braga, 2007), and the occurrence of local summer Skeletonema cf. costatum blooms have been associated with increases in light availability resulting from enhanced
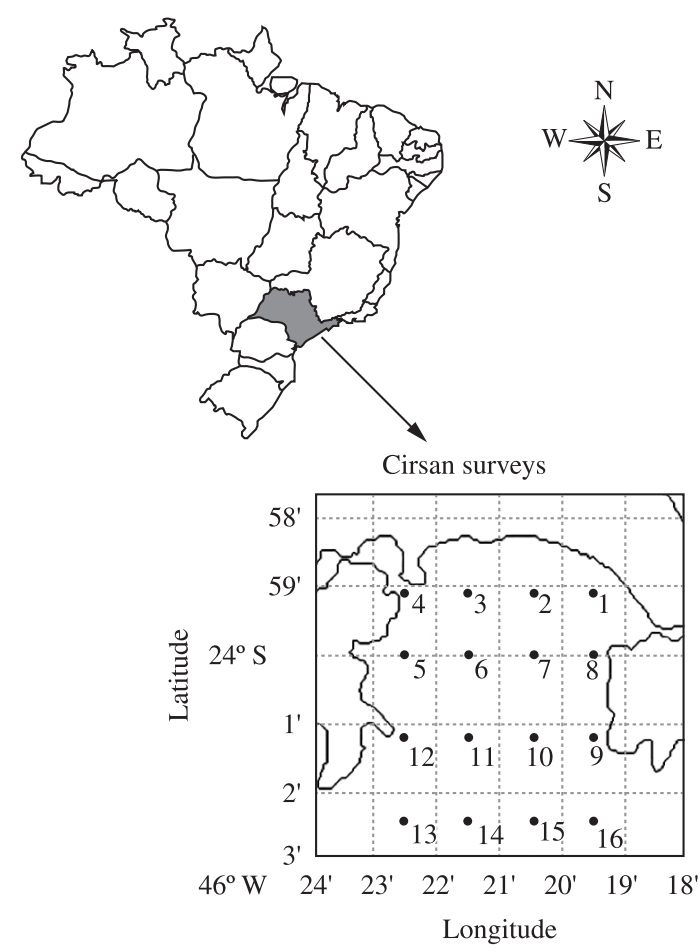

Figure 1. Santos bay location and sampling stations.

vertical stability (Moser et al., 2005). During the winter months, passages of atmospheric cold frontal systems increase wave energy in Santos bay and adjacent sand beaches, leading to blooms of Asterionellopsis glacialis to occur (Villac and Noronha, 2008). To date, there are no conceptual relationships developed among freshwater inputs, tides and wave action on phytoplankton species composition for the Santos estuarine complex area.

Important changes, driven by human impacts in the past decade, are documented for Santos bay and adjacent estuaries, which include a growing volume of domestic sewage disposal and continuous dredging of bottom sediments from the Santos estuarine channel (Schmiegelow et al., 2008). Recent phytoplankton taxonomic surveys report increases in both occurrence and abundance of potentially harmful and mixotrophs dinoflagellates such as Dinophysis acuminata and a number of species from the Prorocentrum genera (Villac et al., 2008).

In this study we discuss the relationships of bloomforming microphytoplankton abundances in an urbanised estuarine complex (Santos bay, Brazil), systematically observed during distinct tides, wind-induced mixing conditions, and freshwater outflow episodes, in the summer and winter months of 2006 and 2007. Our goals were to develop a preliminary conceptual model of phytoplankton dominance in a highly impacted subtropical estuarine complex and to identify scenarios for potential growth of bloom forming microphytoplankton species. 


\section{Material and Methods}

Santos bay has an average depth of $9.3 \mathrm{~m}$ and an area of $44.45 \mathrm{~km}^{2}$, and is semi-open to the Atlantic Ocean. Gradients of water temperature between winter and summer are in the order of $4.5^{\circ} \mathrm{C}$. Precipitation rates are significantly higher in the summer, and wind velocities are higher during winter (Harari et al., 2008). Tides are semi-diurnal and are of less than a metre in amplitude, but together with remote (mesoscale) winds, control the dynamics of local water masses and vertical mixing (Alfredini et al., 2008).

The sampling design used in the present study consisted of eight surveys in Santos bay, performed during March 2006 and March 2007, and during August 2006 and September 2007, to represent the end of summer and winter, respectively. In each selected month, two 10-hour surveys were conducted during spring (ST) and neap tides (NT) (as shown in Table 1), sampling a grid of 16 stations (Figure 1). Two vessels were used simultaneously to minimise sampling time.

Mesoscale wind speeds and current velocities were modelled hourly for each month of observation, using the National Centre for Environmental Prediction/National Centre for Atmospheric Research model (NCEP/NCAR, Kalnay et al., 1996). In situ precipitation rates were obtained from a gauge station, located at $23^{\circ} 57^{\prime} \mathrm{S}$ and $46^{\circ} 18^{\prime} \mathrm{W}$. Wind and precipitation rates model outputs and in situ data, respectively, were averaged for a period of 5 days (four prior the samplings) to minimise the influence of short-term events. Wind direction is presented as N-S and E-W components.

Vertical profiles of temperature and salinity were obtained for stations located above the $10 \mathrm{~m}$ isobath with a CTD (Seabird, Seacat). Water transparency was estimated with a Secchi disk. Water samples were collected with clean plastic buckets at the surface, and at 1-2 $\mathrm{m}$ above the bottom using horizontal van Dorn bottles. Samples were analysed for salinity, total and organic particulate matter (PM and POM) concentrations, chlorophyll- $a$ concentration, and microphytoplankton composition and enumeration. Discrete surface and near-bottom salinity samples were measured with an AUTOSAL salinometer (Beckman RS10). The instantaneous degree of vertical mixing was estimated by differences in salinity measured near bottom and at the surface $(\Delta \mathrm{S})$.

From 250 to $500 \mathrm{~mL}$ were filtered, immediately after sampling, onto pre-dried and weighted Whatman GF/F filters, for quantification of particulate matter (mg.L $\mathrm{L}^{-3}$ ). Filters were kept in the dark in tightly sealed containers containing silica gel pellets until laboratory analysis for total (PM) and organic suspended particulate matter (POM) by the gravimetric method (APHA, 1985).

A volume of $250 \mathrm{~mL}$ of sample was concentrated on GF/F filters, and stored in liquid nitrogen immediately after filtration for quantification of chlorophyll- $a$ concentration $\left(\mathrm{chl}, \mathrm{mg} \cdot \mathrm{m}^{-3}\right)$. The filters were extracted at $-10{ }^{\circ} \mathrm{C}$, for at least 24 hours, in pre-cooled $90 \%$ acetone: DMSO solution (6:4 by volume) (Shoaf and Lium, 1976). Chlorophyll was measured in a routinely calibrated Turner Designs Trilogy fluorometer, following the method proposed by Welschmeyer (1994).

Phytoplankton composition were analysed only in surface samples, from aliquots of $100 \mathrm{ml}$, preserved with buffered formaldehyde ( $0.4 \%$ final concentration) and stored at room temperature in the dark. Sub samples of 10 to $25 \mathrm{~mL}$ were placed in sedimentation chambers (Utermöhl, 1958) and phytoplankton was identified and enumerated

Table 1. Sampling surveys, total of sampling points, sampling days for neap (NT) and spring tides (ST) surveys and variables abbreviators utilized in statistical analysis.

\begin{tabular}{|c|c|c|c|}
\hline Months/ Sampling days & Surveys & $\begin{array}{c}\text { Total of } \\
\text { sampling points }\end{array}$ & Variables \\
\hline $\begin{array}{c}\text { March } 2006 \\
03 / 07 \\
03 / 13\end{array}$ & $\begin{array}{l}\text { Neap (MN06) and } \\
\text { Spring (MS06) }\end{array}$ & 75 & $\begin{array}{l}\text { CHL, PM, POM, PPT, SAL, } \Delta \mathrm{S}, \mathrm{SECCHI}, \\
\text { WIND, SK, AG, GF, GS, CH, HH, TH, } \\
\text { LM, PN, NV, DA, PM, PG, ST, GY, CT }\end{array}$ \\
\hline $\begin{array}{l}\text { August } 2006 \\
08 / 16 \\
08 / 25\end{array}$ & $\begin{array}{l}\text { Neap (AN06) and } \\
\text { Spring (AS06) }\end{array}$ & 73 & $\begin{array}{l}\text { CHL, PM, POM, PPT, SAL, } \Delta \mathrm{S}, \mathrm{SECCHI}, \\
\text { WIND, SK, AG, GF, GS, CH, HH, TH, } \\
\text { LM, PN, NV, DA, PM, PG, ST, GY, CT }\end{array}$ \\
\hline $\begin{array}{c}\text { March } 2007 \\
03 / 13 \\
03 / 20\end{array}$ & $\begin{array}{l}\text { Neap (MN07) and } \\
\text { Spring (AS07) }\end{array}$ & 80 & $\begin{array}{l}\text { CHL, PM, POM, PPT, SAL, } \Delta \mathrm{S}, \text { SECCHI, } \\
\text { WIND, SK, AG, GF, GS, CH, HH, TH, } \\
\text { LM, PN, NV, DA, PM, PG, ST, GY, CT }\end{array}$ \\
\hline $\begin{array}{c}\text { September } 2007 \\
09 / 04 \\
09 / 11\end{array}$ & $\begin{array}{l}\text { Neap (SN07) and } \\
\text { Spring (SS07) }\end{array}$ & 70 & $\begin{array}{l}\text { CHL, PM, POM, PPT, SAL, } \Delta \text { S, SECCHI, } \\
\text { WIND, SK, AG, GF, GS, CH, HH, TH, } \\
\text { LM, PN, NV, DA, PM, PG, ST, GY, CT }\end{array}$ \\
\hline
\end{tabular}

Salinity SAL (p.s.u.); $\Delta$ S; Chlorophyll- $a$ CHL $\left(\mathrm{mg} . \mathrm{m}^{-3}\right)$; particulate matter PM (mg.L $\left.\mathrm{L}^{-1}\right)$; particulate organic matter POM (\% of total PM); coloured disolved organic matter CDOM (absorption); Secchi disk depth SECCHI (m); winds WIND $\left(\mathrm{m} . \mathrm{s}^{-1}\right)$, precipitation rates PPT $\left(\mathrm{mm}\right.$. day $\left.^{-1}\right)$; and densities (cell.L $\mathrm{L}^{-1}$ ) of abundant species: Skeletonema $\mathrm{cf}$. costatum (SK); Guinardia flaccida (GF), Guinardia striata (GS), Chaetoceros (CH), Hemiaulus hauckii (HH), Thalassiosira spp. (TH), Leptocylindrus minimus (LM); Asterionellopsis glacialis (AG), Pseudo-nitzschia spp. (PN), Navicula sp.1 (NV), Dinophysis acuminata (DA), Prorocentrum minimum (PM), Prorocentrum gracile (PG), Gymnodinium spp. (GY), Scrippsiella trochoidea (ST) and Chattonella cf. antiqua (CT). 
under an inverted light microscope (Zeiss, Axiovert) at $400 \times$ magnification. At least 200 cells were counted for microphytoplankton (Lund et al., 1958), identified according to Tomas (1997) and Tenenbaum et al. (2004). Species were considered abundant when their observed numbers were above the mean of a particular cruise in at least $55 \%$ of the stations (Lobo and Leighton, 1986), in this case in 9 of the 16 stations.

For the statistical analyses, density of abundant phytoplanktonic organisms were grouped according to i) tidal conditions: neap and spring tides; ii) time of the year: summer and winter seasons; and iii) year of survey: 2006 and 2007. One-way ANOVA tests were applied to $\log$-transformed cell density data $\left(\log _{10} x+1\right)$, after a priori homogeneity test. Results from ANOVA were tested a posteriori with a Tukey test (Zar, 1999). Spearman correlation tests were applied to the entire data set (Table 1) to detect significant correlations $(\mathrm{p}<0.05)$ between abundant species and environmental data. A Canonical Correspondence Analysis (CCA) was applied to verify the relationships between the density of abundant microphytoplanktonic species and the complementary observed variables, after log-transforming the data (Table 1). A Monte Carlo permutation test, followed by a stepwise forward selection was carried out to determine the significance of the correlations between the environmental and species data. The analyses were carried out with the CANOCO software package, version 4.0 .

\section{Results}

In most surveys, weak to moderate northern winds (around $2.5 \mathrm{~m} . \mathrm{s}^{-1}$ ) prevailed during the 5-day window preceding the samplings. Southern winds were observed in March 2006 NT and in August 2006 ST surveys (Figure 2), and both September 2007 surveys, moderate easterly winds were unusually persistent. Hereafter, the individual surveys will be identified as their respective months and years, followed by NT or ST to discriminate between neap and ST.

Precipitation rates were low during the March surveys (mean values bellow 6 mm.day ${ }^{-1}$, see Table 2), except for the ST survey of 2007, when values were closer to the summer climatology (about $30 \mathrm{~mm} \cdot \mathrm{day}^{-1}$ ) (DAEE, 2009). In all winter surveys (August 2006 and September 2007), average precipitation rates were also lower than climatological values, 15 mm.day ${ }^{-1}$ (DAEE, 2009).

Salinities were generally higher than 30 except during September 2007, when values were below 28 (Figure 3); salinities were also low in near bottom waters during
September 2007-NT. Higher salinity was observed in March 2006-ST, and a clear vertical salinity gradient $(\Delta \mathrm{S})$ was observed during both March 2007 surveys. Salinity was not directly related to precipitation rates, with high values observed following rainy events, in March 2006 and 2007 (as shown in Table 2 and Figure 3), but were negatively correlated to winds from EW quadrant, and positively correlated to the vertical salinity gradient $(\Delta S)$ (Table 3$)$.

Secchi disk depths were around $2 \mathrm{~m}$ for all surveys, with slightly more transparent waters observed during March 2007-NT, when salinities varied from 31 to 32 (Figure 3). The highest total particulate matter (PM) of 109.3 mg.L. . $^{-1}$ was detected in August 2006 ST. Low PM values were observed in all NT surveys (Figure 3 ). In both September 2007 observations, PM were about one third of the remaining surveys, followed by an increase of the relative contribution of POM, notably during that of the NT. Percentage of POM were positively correlated to southern winds, chlorophyll- $a$ and suspended matter concentrations. Chlorophyll concentrations varied from $1.1 \mathrm{mg} . \mathrm{m}^{-3}$ (March $2006 \mathrm{NT}$ ) and $37.9 \mathrm{mg} \cdot \mathrm{m}^{-3}$ (August 2006-NT), and were positively correlated to salinity and PM.

During all surveys, a total of 159 microphytoplankton taxa were found, and 59\% were diatoms. Leptocylindrus minimus, Thalassiosira sp.1, Pseudo-nitzschia species (complex Pseudonitzschia seriata - sensu Hasle, 1965), Guinardia striata, Chaetoceros species, Skeletonema cf. costatum, Hemiaulus hauckii, and Navicula sp.1 occurred in all surveys, and abundances of the first five were positively correlated to chlorophyll- $a$ concentration (Table 3 ). The second most abundant microphytoplankton group was dinoflagellates (29\%), with Prorocentrum minimum, Prorocentrum gracile, Scrippsiella trochoidea and Gymnodinium sp.1 also present in all surveys (Table 4). The remaining groups (19 taxa) were silicoflagellates, ciliophora, microphytoplanktonic flagellates and cyanobacteria (in decrescent order of numerical importance). Diatoms (chain-forming centric and pennate of the complex Pseudo-nitzschia seriata - sensu Hasle, 1965 and some dinoflagellates species (Prorocentrum minimum and Scrippsiella trochoidea) were generally observed in high densities during NTs, when chlorophyll- $a$ concentrations were also high (Figure 3 ).

One-way ANOVA tests applied to the densities of abundant microphytoplankton and using as discrimant factors: tide (Neap $\times$ Spring); seasons (summer $\times$ winter), and year $(2006 \times 2007)$; showed significant differences $(\mathrm{p}<0.05)$ between years (number of samples $=126$; $\mathrm{F}=11.8 ; \mathrm{p}=0.0008)$ and to a lesser extent between tides (number of samples $=126 ; \mathrm{F}=13.79 ; \mathrm{p}=0.0003$ ),

Table 2. Average and standard deviation (between brackets) of WIND (speed, $\mathrm{m} \cdot \mathrm{s}^{-1}$ ) and PPT (precipitation rates mm.day ${ }^{-1}$ ) for surveys held in 2006 and 2007, spring and neap tides.

\begin{tabular}{lcccccccc}
\hline \multicolumn{1}{c}{ Month } & \multicolumn{2}{c}{ Mar./06 } & \multicolumn{2}{c}{ Aug./06 } & \multicolumn{2}{c}{ Mar./07 } & \multicolumn{2}{c}{ Sep./07 } \\
\hline Tide & Neap tide & Spring tide & Neap tide & Spring tide & Neap tide & Spring tide & Neap tide & Spring tide \\
WIND $_{\text {SP }}$ & $1.60(0.7)$ & $2.25(0.81)$ & $1.9(0.62)$ & $2.41(0.73)$ & $1.32(0.41)$ & $1.60(0.91)$ & $2.92(1.15)$ & $2.87(0.78)$ \\
WIND $_{\text {DIR }}$ & NW & SE & N-NE & E-NE & N-NE & NW & E-SE & SE-NE \\
PPT & $5.38(7.01)$ & $4.42(9.88)$ & $0.00(0.00)$ & $1.57(3.52)$ & $5.54(11.9)$ & $21.34(38.02)$ & $0.00(0.00)$ & $0.00(0.00)$ \\
\hline
\end{tabular}


March/2006

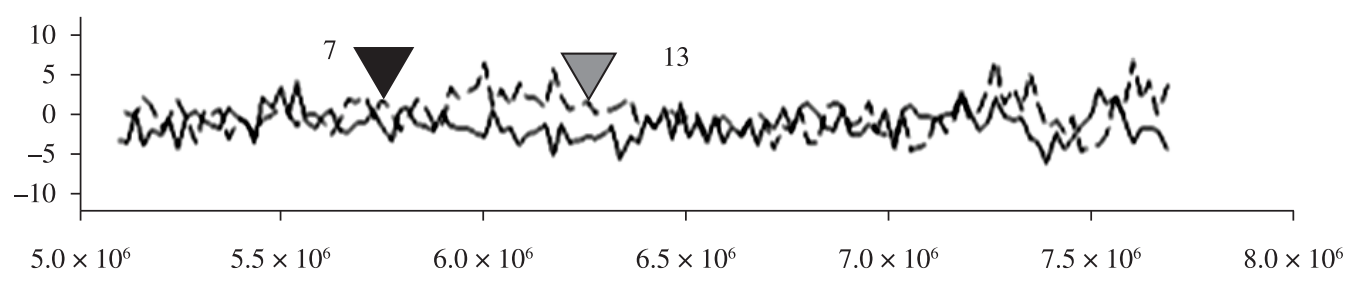

August/2006

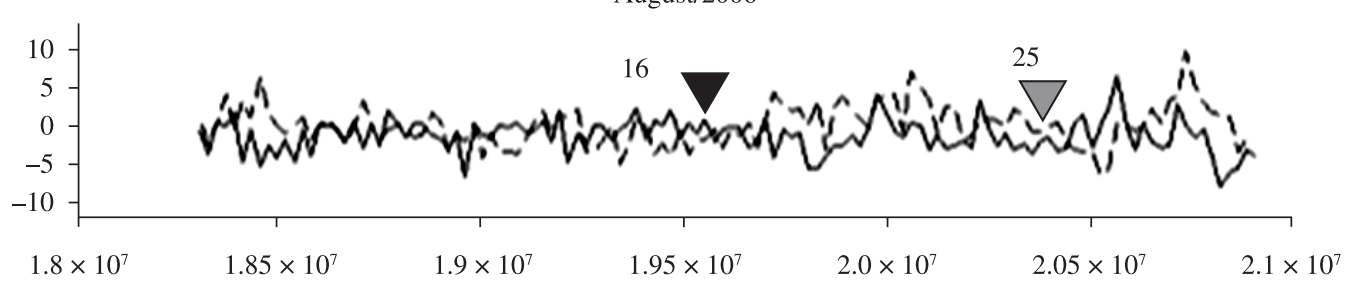

$\operatorname{March} / 2007$
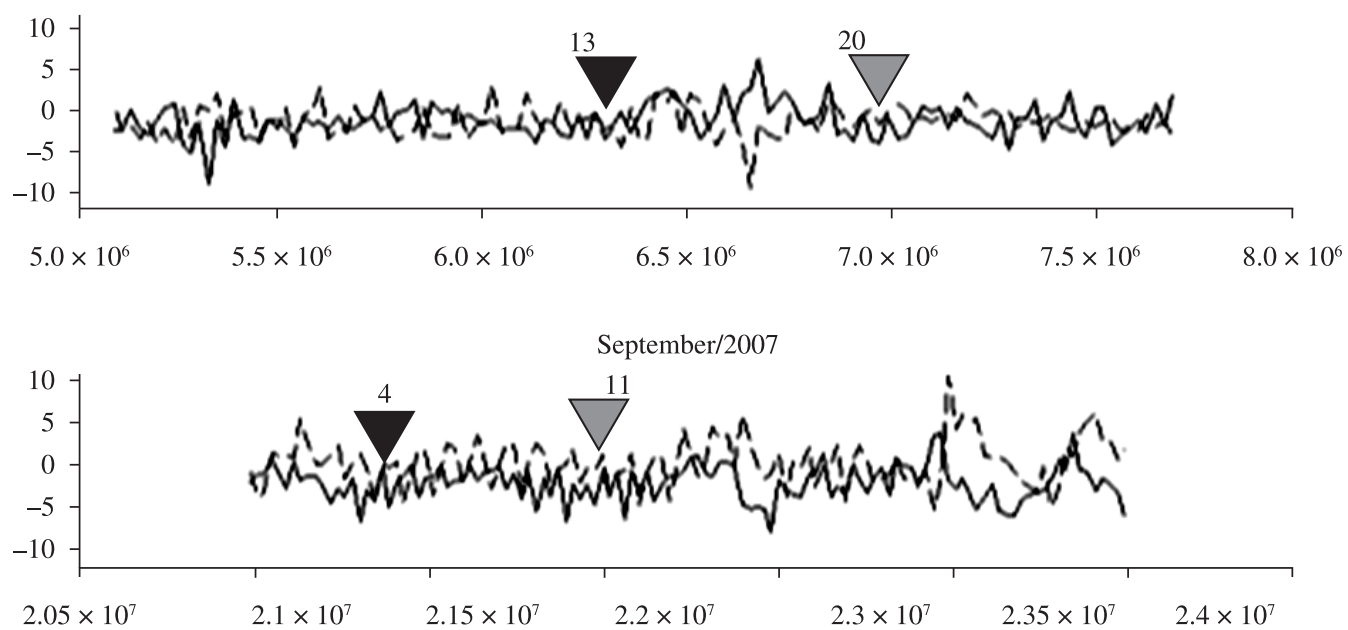

— East - West $\quad \cdots . .$. North - South

Figure 2. Wind velocity, component E-W and N-S along months (March/2006 and 2007; August/2006 and September/2007), neap tide (black arrow) and spring tide (gray arrow) surveys are highlighted.

showing no seasonal significant variability. These results were confirmed with a posteriori Tukey tests.

Both spearman correlations (Table 3) together with CCA analysis (Figure 4) suggested that five groups with distinct microphytoplanktonic dominance, as well as chlorophyll-a and PM and POM values, could be related to salinity, tides, precipitation rates, and wind direction and speed (Tables 4 and 5; Figure 5).

Group 1 (surfers), composed by Asterionellosis glacialis (surf zone diatom- Group 1) was abundant in 2 of our 8 observations, August 2006 NT and ST surveys. Abundances increased when southern winds prevailed (notably in August 2006-ST). Wind speeds were above $5 \mathrm{~m} \cdot \mathrm{s}^{-1}$ in several occasions resulting from the passage of an intense and persistent atmospheric cold front. PM also increased, probably from bottom sediments resuspension.

Group 2, composed of larger diatoms, Hemiaulus hauckii and Guinardia flaccida, called here sinkers, was abundant in 4 of our 8 observations March 2006-NT, March 2006-ST, March 2007-ST and August 2006-NT. Moderate north winds and rainfall, as observed in March 2006 and March 2007, were associated with high abundances of Hemiaulus hauckii and Guinardia flaccida, notably during STs. Both chain forming diatoms with large cell-sizes (diameter $>10 \mu \mathrm{m}$ ). Guinardia flaccida highest densities were observed in August 2006, NT, associated with winds from North and ressuspension, as observed for Asterionellopsis glacialis. 
(a)

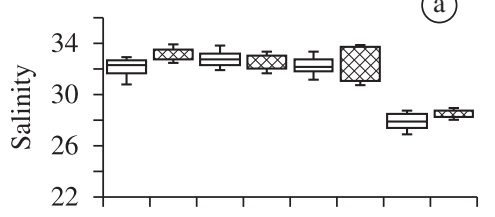

(b)

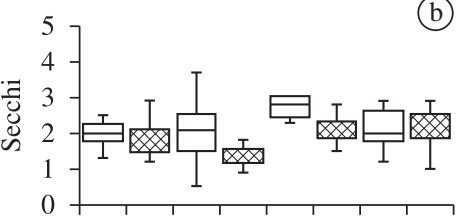

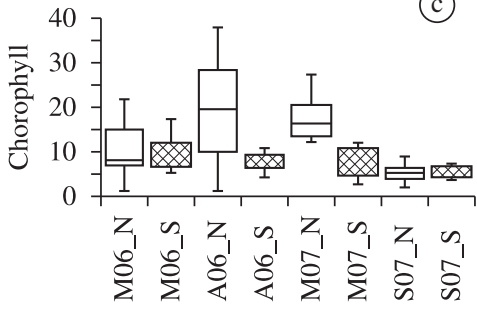

(d)

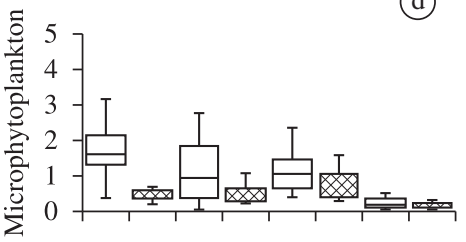

(e)

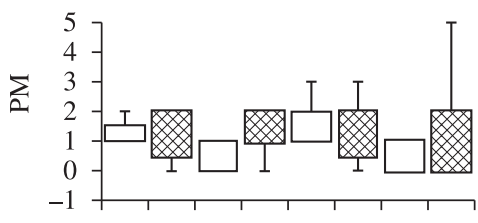

(g)

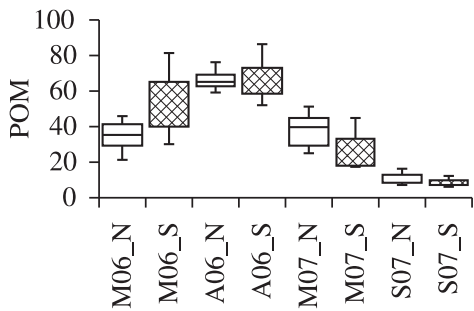

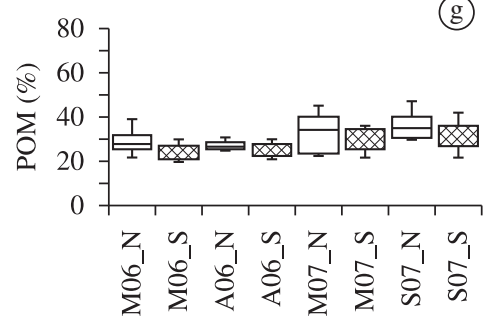

Figure 3. Variation among surveys of: a) Salinity (psu); b) Secchi disk depth (m); c) chlorophyll (mg m³ d) microphytoplankton density ( $x^{1} 10^{6}$ cell $\left.\mathrm{L}^{-1}\right)$; e) $\Delta \mathrm{S}$; f) particulate matter $\mathrm{PM}\left(\mathrm{mg} \mathrm{L}^{-1}\right)$; g) particulate organic matter POM (as \% of total PM). Surveys codes: March 2006 neap tide (M06_N), March 2006 spring tide (M06_S), August 2006 neap tide (A06_N), August 2006 spring tide (A06_S), March 2007 neap tide (M07_N), March 2007 spring tide (M07_S), September 2007 neap tide (S07_N), and September 2007 spring tide (S07_S). box plots- top of the tail is the highest score for the variable and the bottom of the tail is the lowest score; the box signifies the upper and lower quartiles and the median is represented by a short black line within the box.

Group 3, composed of Leptocylindrus minimus, Thalassiosira, Guinardia striata and several Chaetoceros and Pseudo-nitzschia, opportunistic mixers, was observed in higher densities in 3 surveys, March 2006-NT, March 2007-NT and August 2006-NT, associated with higher precipitation rates in March surveys. These small to mediumsize chain-forming diatoms were positively correlated to precipitation rates and North winds. They were abundant in both NT surveys during March 2006 and August 2006, when chlorophyll concentration was also high. These species were also present in all March 2007 and September 2007 surveys, but the highest densities were observed in March 2006 and March 2007 NT surveys, associated with northern quadrant winds and high precipitation rates.

Group 4, composed by mixotrophic dinoglagellates (Dinophysis acuminata and Gymnodinium species), a flagellate (Chattonella cf. antiqua) and a pennate diatom (Navicula sp.), was abundant in 2 surveys, March 2006, NT and ST, probably due to ressuspension and associated with a higher POM contribution to PM, since the higher densities were observed in stations 1, 4, 5 and 8 , near the estuarine channel mouth. Dinophysis acuminata, treated individually, occurred in 3 situations, March 2006 NT, and September 2007, spring and NTs, with higher densities in the last surveys, associated with $\mathrm{E}$ winds and estuarine discharge (lower salinity values). Dinophysis acuminata, Chattonella cf. antiqua and Gymnodinium species were positively correlated to East and West winds. The lowest salinities in both September 2007 surveys, accompanied an overall decrease in microphytoplankton densities and chlorophyll- $a$ concentrations, as well (as shown in Tables 2 and 4 and also in Figure 3), while POM contribution to PM were the highest of all surveys. Precipitation rates previous to September 2007 observations were low, but eastern winds favour estuarine discharge.

Group 5, Skeletonema cf. costatum, Prorocentrum minimum, Prorocentrum gracile and Scrippsiella trochoidea, local mixers, was abundant in all surveys, and higher densities were attained in March 2006, NT conditions, high salinity and strong North winds. 
Table 3. Spearman correlations for environmental data and species. Only significant data $(\mathrm{p}<0.05)$ are presented. Symbols follow Table 1.

\begin{tabular}{|c|c|c|c|c|c|c|c|c|c|c|c|c|c|c|c|c|}
\hline \multirow{2}{*}{$\overline{\text { SAL }}$} & & \multirow[t]{2}{*}{ SAL } & \multicolumn{2}{|r|}{$\Delta \mathbf{S}$} & \multirow[t]{2}{*}{ CHL } & \multicolumn{2}{|c|}{ PM } & \multirow[t]{2}{*}{ POM } & \multicolumn{2}{|c|}{ CDOM } & \multicolumn{2}{|c|}{ SECCHI } & $\begin{array}{l}\text { WIND } \\
\text { E-W }\end{array}$ & \multicolumn{2}{|c|}{$\begin{array}{c}\text { WIND } \\
\text { N-S }\end{array}$} & \multirow[t]{2}{*}{ PPT } \\
\hline & & & & & & & & & & & & & & & & \\
\hline \multicolumn{2}{|l|}{$\Delta \mathbf{S}$} & -0.25 & & & & & & & & & & & & & & \\
\hline \multicolumn{2}{|l|}{ CHL } & 0.21 & & 0.36 & & & & & & & & & & & & \\
\hline \multicolumn{2}{|l|}{ PM } & 0.57 & & & 0.41 & & & & & & & & & & & \\
\hline POM & & -0.32 & & & & & 60 & & & & & & & & & \\
\hline CDOM & & -0.29 & & & & & 15 & & & & & & & & & \\
\hline SECCHI & & & & & & & 37 & 0.21 & & 0.24 & & & & & & \\
\hline WIND E-V & & -0.41 & & & 0.44 & & 27 & & & & & & & & & \\
\hline WIND N-S & & 0.18 & & & -0.36 & & 30 & & & & -0.24 & & -0.64 & & & \\
\hline PPT & & & & 0.32 & 0.42 & & & & & & 0.21 & & -0.21 & & & \\
\hline SK & & & & 0.22 & 0.33 & & & & & & -0.21 & & & & & \\
\hline AG & & 0.26 & & & 0.27 & & 57 & -0.21 & & & 0.23 & & & 0.41 & & \\
\hline GF & & 0.42 & & & 0.18 & & 34 & -0.21 & & & & & & 0.21 & & \\
\hline GS & & & & 0.18 & 0.23 & & 18 & 0.25 & & & 0.28 & & -0.22 & 0.36 & & 0.27 \\
\hline $\mathbf{C H}$ & & & & 0.34 & 0.26 & & & & & & & & -0.49 & 0.23 & & 0.32 \\
\hline HH & & 0.32 & & & & & & & & & & & -0.28 & 0.18 & & 0.41 \\
\hline TH & & 0.18 & & 0.30 & 0.39 & & & & & & & & -0.58 & 0.54 & & 0.28 \\
\hline LM & & & & 0.21 & 0.32 & & & & & & & & -0.55 & 0.5 & & 0.23 \\
\hline PN & & & & 0.30 & 0.53 & & 22 & & & & & & -0.59 & 0.36 & & 0.59 \\
\hline NV & & & & & -0.22 & & 27 & 0.18 & & & & & 0.17 & & & \\
\hline DA & & -0.55 & & & -0.40 & & 39 & 0.29 & & & & & 0.56 & -0.43 & & -0.41 \\
\hline PM & & & & & & & & & & & & & -0.15 & -0.15 & & \\
\hline PG & & & & & & & 26 & & & & & & -0.20 & -0.18 & & \\
\hline ST & & 0.27 & & & -0.26 & & 34 & & & & & & -0.30 & -0.14 & & \\
\hline GY & & -0.21 & & & -0.29 & & 25 & & & & & & 0.20 & -0.30 & & \\
\hline CT & & & & & -0.21 & & 30 & & & & & & 0.18 & -0.25 & & \\
\hline & SK & AG & GF & GS & $\mathrm{CH}$ & HH & TH & LM & PN & NV & DA & PM & PG & ST & GY & CT \\
\hline SAL & & 0.26 & 0.42 & & & 0.32 & 0.18 & & & & -0.55 & & & 0.27 & -0.21 & \\
\hline$\Delta \mathbf{S}$ & 0.22 & & & 0.18 & 0.34 & & 0.30 & 0.21 & 0.30 & & & & & & & \\
\hline CHL & 0.33 & 0.27 & 0.18 & 0.23 & 0.26 & & 0.39 & 0.32 & 0.53 & -0.22 & -0.40 & & & -0.26 & -0.29 & -0.21 \\
\hline PM & & 0.57 & 0.34 & -0.18 & & & & & 0.22 & -0.27 & -0.39 & & 0.26 & 0.34 & -0.25 & -0.30 \\
\hline POM & & -0.21 & -0.21 & 0.25 & & & & & & 0.18 & 0.29 & & & & & \\
\hline CDOM & & & & & & & & & & & & & & & & \\
\hline SECCHI & -0.21 & 0.23 & & 0.28 & & & & & & & & & & & & \\
\hline $\begin{array}{l}\text { WIND } \\
\text { E-W }\end{array}$ & & & & -0.22 & -0.49 & -0.28 & -0.58 & -0.55 & -0.59 & 0.17 & 0.56 & -0.15 & -0.20 & -0.30 & 0.20 & 0.18 \\
\hline $\begin{array}{l}\text { WIND } \\
\text { N-S }\end{array}$ & & 0.41 & 0.21 & 0.36 & 0.23 & 0.18 & 0.54 & 0.5 & 0.36 & & -0.43 & -0.15 & -0.18 & -0.14 & -0.30 & -0.25 \\
\hline PPT & & & & 0.27 & 0.32 & 0.41 & 0.28 & 0.23 & 0.59 & & -0.41 & & & & & \\
\hline SK & & 0.23 & & & 0.2 & & & & 0.3 & & & 0.34 & & & & \\
\hline AG & & & 0.49 & & & -0.26 & & & & & -0.31 & & 0.21 & & & \\
\hline GF & & & & & & & & & & & & & & & & \\
\hline GS & & & & & 0.24 & & 0.25 & 0.28 & 0.40 & & & 0.32 & & & & 0.21 \\
\hline CH & & & & & & 0.32 & 0.56 & 0.45 & 0.54 & & -0.27 & 0.30 & & & & \\
\hline HH & & & & & & & 0.21 & & 0.36 & & -0.20 & & & 0.28 & & \\
\hline TH & & & & & & & & 0.44 & 0.53 & & -0.40 & & & 0.37 & & \\
\hline LM & & & & & & & & & 0.37 & & -0.29 & & & & & \\
\hline PN & & & & & & & & & & -0.21 & -0.49 & 0.41 & 0.22 & 0.27 & -0.20 & \\
\hline NV & & & & & & & & & & & 0.22 & & & & & \\
\hline DA & & & & & & & & & & & & & & -0.23 & 0.20 & \\
\hline PM & & & & & & & & & & & & & 0.30 & & & 0.35 \\
\hline PG & & & & & & & & & & & & & & 0.26 & & \\
\hline ST & & & & & & & & & & & & & & & & \\
\hline GY & & & & & & & & & & & & & & & & 0.25 \\
\hline
\end{tabular}




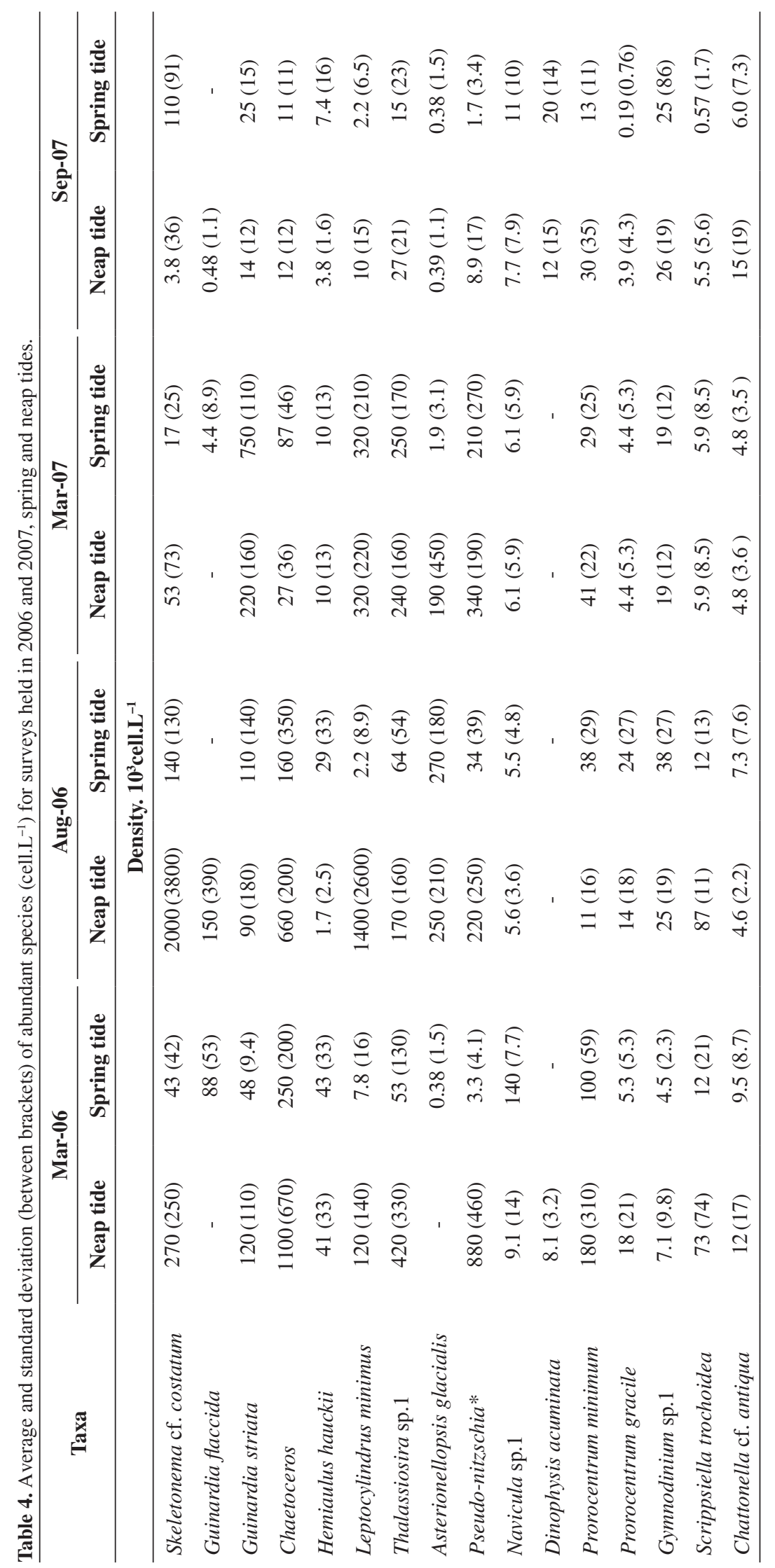




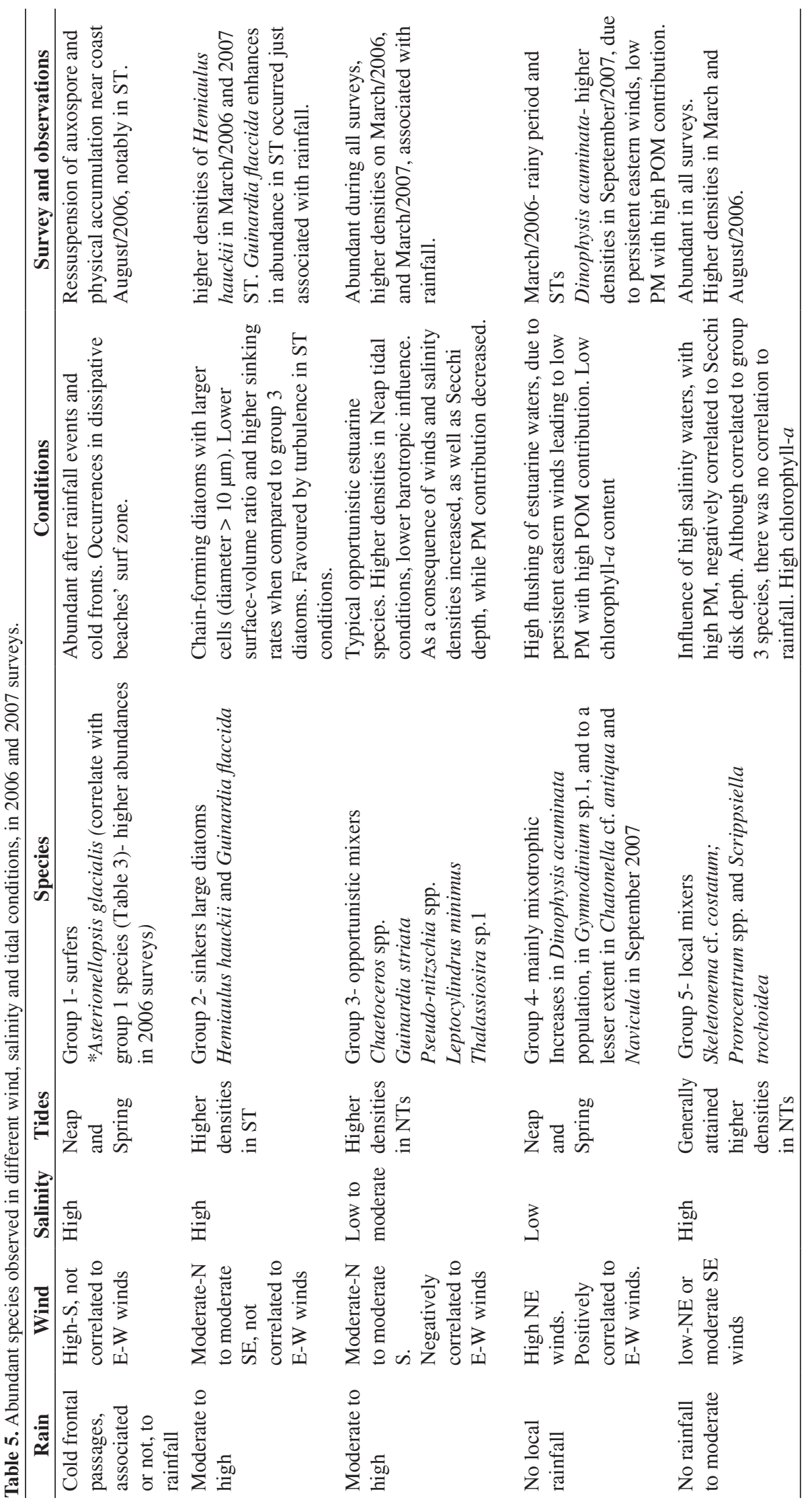




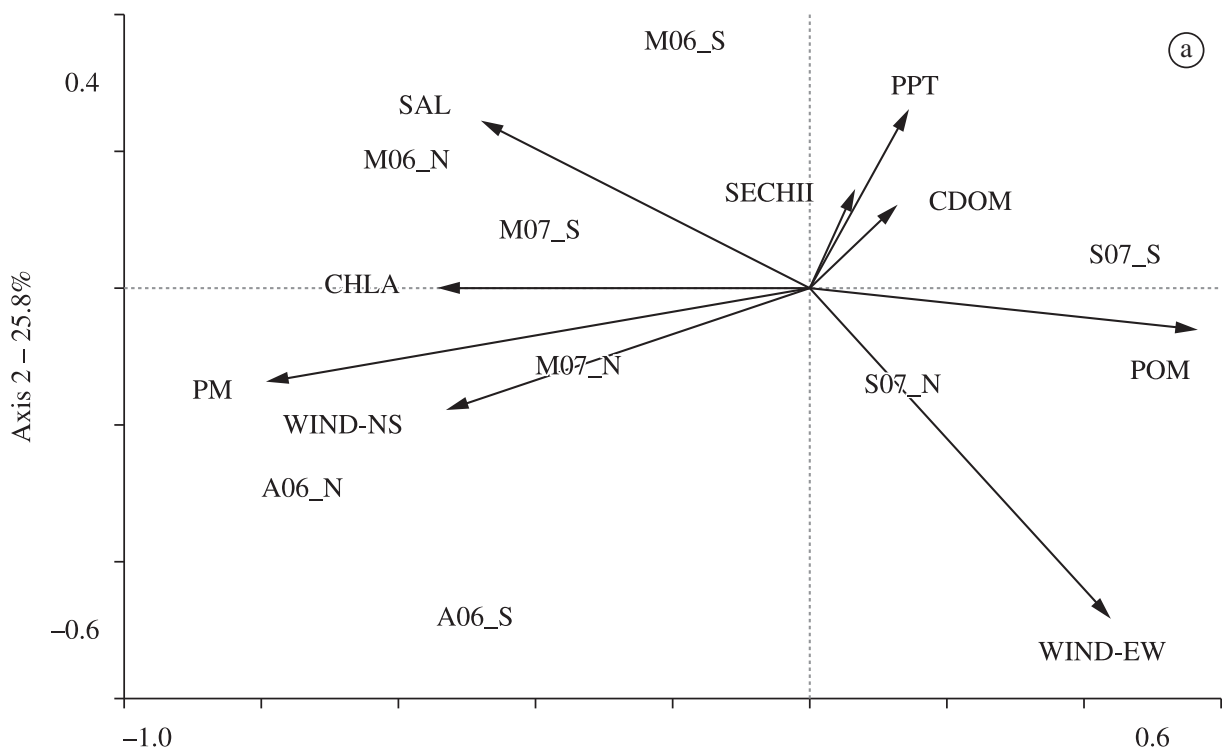

Axis $1-48.5 \%$

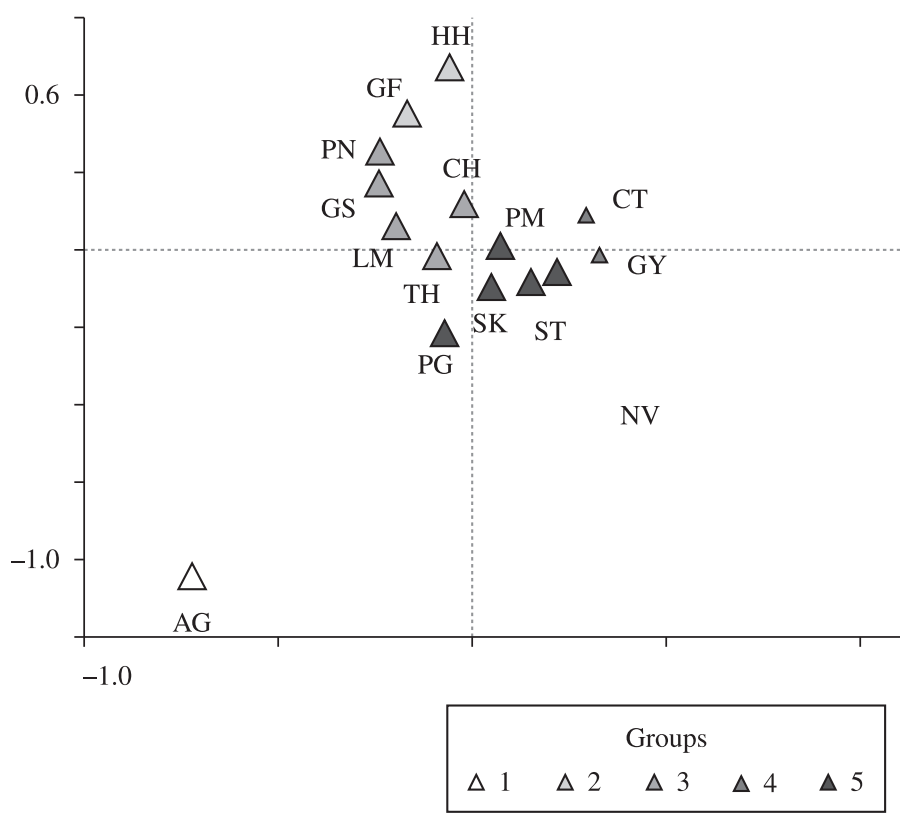

(b)

Figure 4. Factorial plane of environmental variables, surveys (a) and species (b) resulting from Canonical Correlation Analysis (CCA).

\section{Discussion}

\subsection{Patterns for species composition}

Santos bay has an average depth of only $9.5 \mathrm{~m}$, thus wind and tide-driven currents force local transport of dissolved and particulate materials (Geyer, 1997; Durand et al., 2002). Due to the south orientation of Santos bay opening, shifts in wind direction will influence turbulence levels, circulation patterns, and modify estuarine outflows. Our observations showed that changes in chlorophyll- $a$ concentration followed closely the abundances of microphytoplankton species, especially during NTs at the end of summer, always with dominance of diatoms. Previously described mechanisms linking vertical mixing and consequent light availability to local phytoplankton abundance were not always repeated (e.g. Moser et al., 2004; Moser et al., 2005). Nonetheless, the observed contribution of diatoms, dinoflagellates and other phytoplanktonic groups (silicoflagellates, ciliophora, microphytoplanktonic flagellates, and cyanobacteria) to the overall phytoplankton community richness were similar to world coastal seas (Sournia et al., 1991), and systems with large inputs of nutrients (Muylaert et al., 2009). 

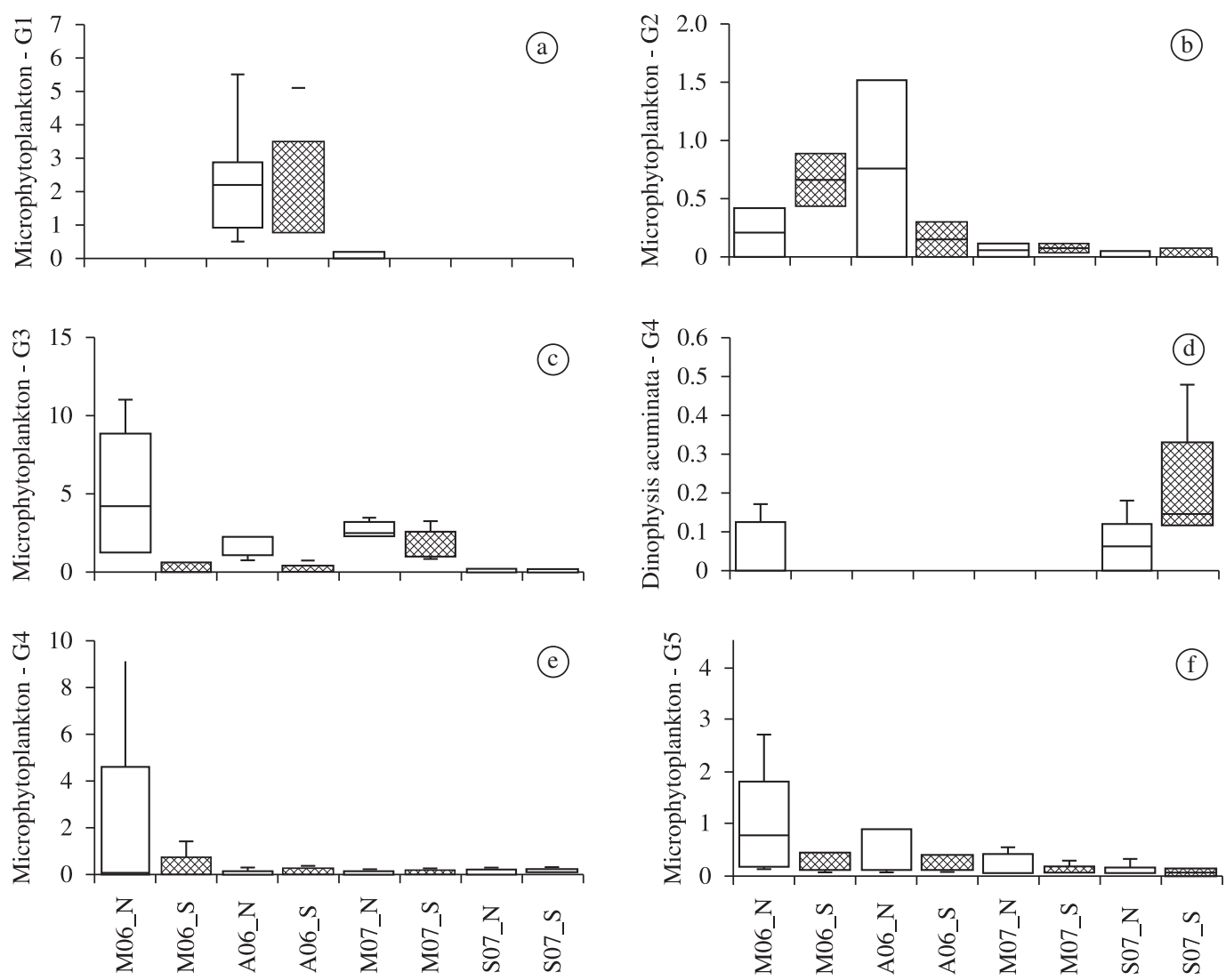

Figure 5. Abundant species grouped by Spearman correlations and Canonical Correspondence Analysis observed in 2006 and 2007 surveys. Densities in x10 cell L-1. a) Group 1 (G1), composed by Asterionellopsis glaciallis; b) Group 2 (G2), composed by Hemiaulus hauckii and Guinardia flaccida; c) Group 3 (G3), composed by Chaetoceros species, Thalassiosira sp1, Pseudo-nitzschia species, Leptocylindrus minimus and Guinardia striata; d) G4- showing only Dinophysis acuminata distribution; e) Group 4 (G4), composed by Navicula, Chatonella cf. antiqua, Gymnodinium sp1 and Dinophysis acuminata;; f) Group 5 (G5) Skeletonema cf. costatum, Prorocentrum spp and Scripsiella trochoidea. box plots- top of the tail is the highest score for density of the group, and the bottom of the tail is the lowest score; the box signifies the upper and lower quartiles and the median is represented by a short black line within the box.

Responses of plankton communities to short-term physical fluctuations allow many species to coexist, but even in a rapidly changing environment, a specific phytoplankton group can dominate. Diatoms have a number of physiological adaptations for local vertical mixing (Cullen and McIntyre, 1998). The dominant diatoms found in our study generally support high metabolism, function of favourable surface-volume ratios (Nogueira and Figueiras, 2005) resulting from small-sized cells and chain-forming (Skeletonema cf. costatum) or elongated cells (Guinardia and Pseudo-nitzschia species). The elongated penate chain forming diatom species observed in Santos Bay may belong to the Pseudo-nitzschia seriata complex (Hasle, 1965). Higher densities were observed during 2006 surveys, varying from $10^{3}$ cell. $\mathrm{L}^{-1}$ to $10^{5}$ cell. $\mathrm{L}^{-1}$, close to the upper limit considered a risk (Mafra-Júnior et al., 2006).

A larger contribution of dinoflagellates to total community (29\%) than previous studies in our study region (less than $10 \%)$ raises concerns towards possible effects of local eutrophication (Aguiar and Braga, 2007). In addition, routine-dredging activities in the Santos estuarine channel can promote dinoflagellates cists suspension (Pitcher and Joyce, 2009). The Santos estuarine channel has been dredged continuously since 2002, and in average, $300000 \mathrm{~m}^{3}$ of sediments are removed every month, and disposed in the adjacent inner continental shelf (ANTAQ, 2009). Local dinoflagellate abundances have coincidentally increased since 2002 (Villac et al., 2008). Prorocentrum minimum is a neritic bloom-forming dinoflagellate, responsible for harmful episodes in many estuarine and coastal environments that have been subjected to significant geographical expansion (Taylor et al., 2003; Heil et al., 2005). Prorocentrum minimum occurred in all surveys in densities above $10^{4}$ cell. $\mathrm{L}^{-1}$, similar to other eutrophised sites, such as Paranaguá bay (Mafra-Júnior et al., 2006) and Santo André Lagoon (Macedo et al., 2001), where densities reached $2.510^{7}$ cell. $\mathrm{L}^{-1}$ during blooms.

As in other eutrophic costal regions, Prorocentrum minimum high abundances seem to co-occur with, or develop after, high abundances 
of Skeletonema cf. costatum (Heil et al., 2005). The processes governing the temporal relationships between these two species are still unknown (Heil et al., 2005). Skeletonema cf. costatum is in fact a composite of distinct species (Sarno et al., 2005; Jinfeng et al., 2008). Thus further studies regarding their co-occurrence are still required, as well as any link to the presence of these species and changes in local eutrophication (Macedo et al., 2001). The lack of seasonal trends observed, in part result from our sample design, was contrary to what is reported in earlier studies. Skeletonema cf. costatum blooms are rather responses to episodic events than characteristic summer-bloom species. Skeletonema cf. costatum was negatively correlated to water transparency, following the expected adaptation to low light conditions (e.g. Sakshaug and Andersen, 1986). Schmiegelow et al. (2008) reported nano-sized flagellates as dominant phytoplankton groups in Santos bay year-round and that shifts to microphytoplanktonic-dominance occur during decreases in mixing and increases in precipitation rates. Neither Macedo et al. (2001) nor Heil et al. (2005) have considered the role of wind intensity and direction that will probably be more decisive establishing light level conditions in a time scale of days to weeks.

\subsection{Microphytoplankton assemblages and the role of weather-induced variability}

Our results show at least five distinct and episodic scenarios of microphytoplankton dominance as responses to winds, tides and rainfall. Northern winds prevailed during the observations, but a number of atmospheric cold frontal systems previous to the August 2006 ST survey, changed winds to the southern quadrant. Increases in Asterionellopsis glacialis abundance, a diatom commonly observed in high-energy surf zones (McLachlan and Brown, 2006), followed the increase in strength of the south wind component. High abundances of A. glacialis in the area, is perhaps a result of auxospores suspension or physical accumulation of vegetative cells (Villac and Noronha, 2008). In addition to watercolour changes, the large amount of mucilage released by these blooms can become vehicles for pollutants (Koukal et al., 2007), thus their occurrence and consequences must be better understood in urbanised areas.

During September 2007 eastern winds atypically persisted for many days prior to both sampling dates, during which we observed the lowest chlorophyll- $a$ concentrations, salinity and microphytoplankton abundances comparing all surveys (Figure 3). Considering the unsignificant local precipitation rates, probably high estuarine outflows were forced by the wind in association with remote precipitation, which occurred in São Paulo, in the vicinity of Congonhas airport (IPMET, 2007). During both September 2007 surveys, mixotrophic dinoflagellates, such as Dinophysis acuminata were abundant. Gymnodinium species and Chattonella cf. antiqua, also potentially harmful bloom-forming species (Hallegraeff, 2004), were also abundant during September 2007. Dinophysis acuminata showed densities of $10^{4}$ cell.L - $^{-1}$ in September 2007 ST survey, above the limits $\left(10^{3}\right.$ cell. $\left.\mathrm{L}^{-1}\right)$ as a risk for public health due to potential DSP toxin production (MafraJúnior et al., 2006). Blooms of Dinophysis acuminata and Gymnodinium species, as well as other dinoflagellates, have been observed after strong rainfall events and in periods of low turbulent mixing in estuaries and bays (Hallegraeff, 2004). In September 2007, these dinoflagellates were able to compete with Skeletonema cf. costatum.

Fluxes of organic material through rivers and estuaries affect coastal phytoplankton growth and composition (Klug and Cottingham, 2001), especially through mixotrophic nutrition where inorganic nutrients (Arenovski et al., 1995) or light (Bockstahler and Coats, 1993) are low. The magnitudes of CDOM light absorption, proxy for DOM concentration, showed highest mean value in September 2007 NT survey (Ciotti, A.M. unpublished data). Humic substances must undergo chemical transformations to become available to bacteria that in turn support mixotrophic organisms. DOM degradation, mainly photochemical, can be an additional source of ammonia and phosphate (Rochelle-Newal and Fisher, 2002). A number of anthropogenic substances (e.g., chlorine) in domestic sewage may perhaps alter DOM characteristics and its availability to microorganisms. Nonetheless, the effects of sewage inputs on chemical and optical characteristics of DOM have been little studied (Staehr et al., 2009), and its consequences to changes in phytoplankton community structures must be addressed.

Tides and precipitation rates were also related to some phytoplanktonic assemblages. Chlorophyll- $a$ concentration and microphytoplanktonic cell densities, mainly Chaetoceros, Pseudo-nitzschia species, Thalassiosira, Guinardia striata and Leptocylindrus minimus were higher during neap than STs, and also after periods of rainfall. Only Hemiaulus hauckii and Guinardia flaccida showed larger densities during STs, (H. hauckii during both 2006 surveys and September 2007; and G. flaccida during summer surveys), probably a result of their larger cell size and hence higher sinking rates (Scharek et al., 1999). On the other hand, Skeletonema cf. costatum, Prorocentrum minimum, Prorocentrum gracile and Scrippsiella trochoidea occurred in all surveys, with enhanced densities during winds from the northern quadrant, high PM and low Secchi disk depths. One possible explanation for the high abundance of Skeletonema cf. costatum observed in August 2006 could be ressuspension of auxospores and resting stages (Harris et al., 1998) from bottom sediments. As $S$. cf. costatum is the most cited bloom-forming organism in the region, it is reasonable to assume the presence of resting stages in Santos bay sediments that could eventually nourish bloom formation. However, as for the majority of diatoms (Davidovich and Bates, 2002), the life cycle mechanisms of Skeletonema cf. costatum are not properly understood.

\section{Conclusions}

Changes in microphytoplankton communities observed in Santos bay coastal waters are episodic, mainly related to wind speed and direction and tides, and to a lesser extent, 
to precipitation rates. Chain forming diatoms with small or elongate cells ("mixers") occurred throughout the surveys, increasing during NTs. Densities of larger celled diatoms, such as Hemiaulus hauckii ("sinkers") increased during $\mathrm{ST}$, after periods of high precipitation rates.

Skeletonema cf. costatum, also a "mixer", was observed in high densities during August 2006 (austral winter) linked to strong N-NE winds, contrary to what has been previously reported, and suggesting an alteration in the temporal patterns of these species blooms, or the existence of local mechanisms for resuspension of resting stages and auxospores.

Strong southern winds increases surf zone energy in Santos bay, common after atmospheric frontal systems. In these situations, Asterionellopsis glacialis blooms are expected on a scale of a few hours to days. The enhancement of atmospheric instabilities will most likely alter the frequency of these blooms in the area, as well as in the remaining dissipative coastal in southern Brazil.

Mixotrophic dinoflagellates, such as Dinophysis acuminata, appear to be able to compete with mixers (bloom-forming diatoms) after intense estuarine discharges, raising concerns about uncontrolled disposals of freshwater into eutrophised systems, especially those surrounding highly urbanised areas.

Densities of Dinophysis acuminata and species of Pseudo-nitzschia seriata complex were above published safe limits, emphasizing the importance of urgent and constant monitoring programmes in the area.

Acknowledgements - We are grateful to the crewmembers of the vessels Danda II, Ilhas do Sul and Lugano and members of Laboratório Aquarela (UNESP-CLP) and Laboratório de Ecologia do Fitoplâncton (UNIMONTE) for support during oceanographic surveys. This research took place within the CIRSAN (Circulation in Santos bay) project, funded by FAPESP (Fundação de Amparo à Pesquisa do Estado de São Paulo- 2003/13747-5). F.C Giannini and R.T. Tonini also received FAPESP scholarships.

\section{References}

ACHA, EM., MIANZAN, H., GUERRERO, R., CARRETO, J., GIBERTO, D., MONTOYA, N. and CARIGNAN, M., 2008. An overview of physical and ecological processes in the Rio de la Plata Estuary. Continental Shelf Research, vol. 28, p. 1579-1588. http://dx.doi.org/10.1016/j.csr.2007.01.031

Agência Nacional de Transportes Aquaviários - ANTAQ, 2009. Relatório de dragagem. Available from: <http://www.antaq.gov.br/ Portal/GestaoAmbiental/Publicacoes.asp >. Access in: 25 jun. 2009.

AGUIAR, VMC. and BRAGA, ES., 2007. Seasonal and tidal variability of phosphorus along a salinity gradient in the heavily polluted estuarine system of Santos/São Vicente - São Paulo, Brazil. Marine Pollution Bulletin, vol. 54, p. 464-488.

ALFREDINI, P., ARASAKI, E. and AMARAL, RF., 2008. Mean sea-level rise impacts on Santos Bay, Southeastern Brazil - physical modelling study. Environmental Monitoring and Assessment, vol. 144 , p. 377-387.
American Public Health Association - APHA, 1985. Standard Methods for the Examination of Water and Wastewater. 16nd ed. Washington: APHA.

ANDERSON, DM., BURKHOLDER, JM., COCHLAN, WP., GLIBERT, PM., GOBLER, CJ., HEIL, CA., KUDELA, RM., PARSONS, ML., JACK RENSEL, JE., TOWNSEND, DW., TRAINER, VL. and VARGO, GA., 2008. Harmful algal blooms and eutrophication: Examining linkages from selected coastal regions of the United States. Harmful Algae, vol. 8 , p. 39-53. http://dx.doi.org/10.1016/j.hal.2008.08.017

ARENOVSKI, AL., LIM, EL. and CARON, DA., 1995. Mixotrophic nanoplankton in oligotrophic surface waters of the Sargasso Sea may employ phagotrophy to obtain major nutrients. Journal of Plankton Research, vol. 17, p. 801-820. http://dx.doi.org/10.1093/ plankt/17.4.801

BAEK, SH., SHIMODE, S., HAN, MS. and KIKUCHI, T., 2008. Growth of dinoflagellates, Ceratium furca and Ceratium fusus in Sagami Bay, Japan: The role of nutrients. Harmful Algae, vol. 7, p. 729-739. http://dx.doi.org/10.1016/j.hal.2008.02.007

BOCKSTAHLER, KR. and COATS, DW., 1993. Spatial and Temporal aspects of mixotrophy in Chesapeake Bay dinoflagellates. Journal of Eukaryotic Microbiology, vol. 40 , p. 49-60. http:// dx.doi.org/10.1111/j.1550-7408.1993.tb04881.x

BRAGA, ES., BONETTI, CVDH., BURONE, L. and BONETTIFILHO, J., 2000. Eutrophication and bacterial pollution caused by industrial and domestic wastes at the Baixada Santista Estuarine System-Brazil. Marine Pollution Bulletin, vol. 40, p. 165-173.

BURKHOLDER, JM., DICKEY, DA., KINDER, CA., REED, RE., MALLIN, MA., MCIVER, MR., CAHOON, LB., MELIA, G., BROWNIE, C., SMITH, J., DEAMER, N., SPRINGER, J., GLASGOW, HB. and TOMS, D., 2006. Comprehensive trend analysis of nutrients and related variables in a large eutrophic estuary: A decadal study of anthropogenic and climatic influences. Limnology and Oceanography, vol. 51, no 1-2, p. 463-487.

CLOERN, JE., 1996. Phytoplankton bloom dynamics in coastal ecosystems: a review with some general lessons from sustained investigation of San Francisco Bay, California. Reviews of Geophysics, vol. 34, p. 127-168. http://dx.doi.org/10.1029/96RG00986

CULLEN, JJ. and MACINTYRE, JG., 1998. Behavior, physiology and the niche of depth-regulating phytoplankton. In ANDERSON, DM., CEMBELLA, AD. and HALLEGRAEFF, GM., (Eds.). Physiological Ecology of Harmful Algal Blooms. Berlin: SpringerVerlag. p. 1-21. NATO ASI Series.

DAVIDOVICH, NA. and BATES, SS., 2002. Pseudo-nitzschia life cycle and the sexual diversity of clones in diatom populations. In Proceedings of the LIFEHAB Workshop: Life history of microalgal species causing harmful algal blooms, 2002. Commission of the European Community. p. 27-30.

DURAND, N., FIANDRINO, A., FRAUNIÉ, P., OUILLON, S., FORGET, P. and NAUDIN, JJ., 2002. Suspended matter dispersion in the Ebro ROFI: an integrated approach. Continental Shelf Research, vol. 22, p. 267-284. http://dx.doi.org/10.1016/ S0278-4343(01)00057-7

GEYER, WR., 1997. Influence of Wind on Dynamics and Flushing of Shallow Estuaries. Estuarine, Coastal and Shelf Science, vol. 44, p. 713-722. http://dx.doi.org/10.1006/ecss.1996.0140

GIANESELLA, SMF., SALDANHA-CORRÊA, FMPP. and TEIXEIRA, C., 2000. Tidal effects on nutrients and phytoplankton 
distribution at Bertioga Channel (SP). Aquatic Ecosystem Health and Management, vol. 3, p. 533-544.

GLIBERT, PM., HEIL, CA., O'NEIL, JM., WILLIAM, C., DENNISON, I. and O'DONOHUE, MJH., 2006. Nitrogen, Phosphorus, Silica, and Carbon in Moreton Bay, Queensland, Australia: Differential Limitation of Phytoplankton Biomass and Production. Estuaries and Coasts, vol. 29, no 2, p. 209-221. http://dx.doi.org/10.1007/BF02781990

HALLEGRAEFF, GM., 2004. Harmful algal blooms: a global overview. In HALLEGRAEFF, GM., ANDERSON, DM. and CEMBELLA, AD., (Eds.). Manual on Harmful Marine Microalgae, Monographs on Oceanographic Methodology. 2nd ed. Paris: Unesco Publishing. p. 25-49.

HARARI, J., FRANÇA, CAS. and CAMARGO, R., 2008. Climatology and Hydrography of Santos Estuary. In NEVES, R., BARETTA, J. and MATEUS, M., (Eds.). Perspectives on Integrated Coastal Zone Management in South America. Lisboa: IST Press. p. 147-160.

HARRIS, ASD., JONES, KJ. and LEWIS, J., 1998. An assessment of the accuracy and reproducibility of the most probable number (MPN) technique in estimating numbers of nutrient stressed diatoms in sediment samples. Journal of Experimental Marine Biology and Ecology, vol. 231, no 1, p. 21-30. http://dx.doi.org/10.1016/ S0022-0981(98)00061-6

HASLE, GR., 1965. Nitzschia and Fragilariopsis species studied in the light and electron microscopes. II. The group Pseudonitzschia. Oslo: Universit Etsforlaget, 1965.

HEIL, CA., GLIBERT, PM. and FAN, C., 2005. Prorocentrum minimum (Pavillard) Schiller A review of a harmful algal bloom species of growing worldwide importance. Harmful Algae, vol. 4, p. $449-470$.

Instituto de Pesquisas Meteorológicas - IPMET, 2007. Eventos extremos do mês de Setembro 2007. Available from: <http://www. ipmet.unesp.br/index.php>. Access in: 22 out. 2010.

JINFENG, C., YANG, L., JUNRONG, L. and YAHUI, G., 2008. Morphological variability and genetic diversity in five species of Skeletonema (Bacillariophyta). Progress in Natural Science, vol. 18, no 11, p. 1345-1355. http://dx.doi.org/10.1016/j.pnsc.2008.05.002

KALNAY, E., KNAMITSU, M., KLISTER, R., COLLINS, W., DEAVEN, D., GANDIN, I., IREDELL, M., SAHA, S., WHITE, G., WOOLLEN, J., ZHU, Y., CHELLIAH, M., EBISUZAKI, E., HIGGINS, W., JANOWISK, J., ROPELEWSKI, KMO; WANG, J.,LEETMA, A., REYNOLDS, R., JENNE, R. and JOSEPH, D., 1996. The ncep/ncar year reanalysis project. Bulletin American Meteorogy Society, vol. 77, p. 437-470. http://dx.doi. org/10.1175/1520-0477(1996)077\%3C0437:TNYRP\%3E2.0.CO;2

KIMMERER, WJ., 2002. Effects of freshwater flow on abundance of estuarine organisms: physical effects or trophic linkages? Marine Ecology Progress Series, vol. 243, p. 39-95. http://dx.doi. org/10.3354/meps243039

KLUG, J. and COTTINGHAM, K., 2001. Interactions among environmental drivers: community responses to changing nutrients and dissolved organic carbon. Ecology, vol. 82 no. 12, p. 33903403. http://dx.doi.org/10.1890/0012-9658(2001)082[3390:IA EDCR]2.0.CO;2

KOUKAL, B., ROSSE, P., REINHARDT, A., FERRARI, B., WILKINSON, KJ., LOIZEAU, JL. and DOMINIK, J., 2007. Effect of Pseudokirchneriella subcapitata (Chlorophyceae) exudates on metal toxicity and colloid aggregation. Water Research, vol. 41, no 1, p. 63-7. http://dx.doi.org/10.1016/j.watres.2006.09.014

LOBO, EA. and LEIGHTON, G., 1986. Estructuras comunitarias de las fitocenosis planctónicas de los sistemas de desembocaduras de rios y esteros de la zona central de Chile. Revista de Biología Marina y Oceanografía, vol. 22, no. 1, p. 1-29.

LUND, JWG., KIPLING, C. and LE CREN, ED., 1958. The inverted microscope method of estimating algal numbers and the statistical basis of estimations by counting. Hydrobiologia, vol. 2, p. 143-170.

MACEDO, MF., DUARTE, P., MENDES, P. and FERREIRA, JG., 2001. Annual variation of environmental variables, phytoplankton species composition and photosynthetic parameters in a coastal lagoon. Journal of Plankton Research, vol. 23, no 7, p. 719-732. http://dx.doi.org/10.1093/plankt/23.7.719

MAFRA-JUNIOR, LL., FERNANDES, L. and PROENÇA, LAO., 2006. Harmful algae and toxins in Paranaguá Bay, Brazil: bases for monitoring. Brazilian Journal of Oceanography, vol. 54, p. 107-121. http://dx.doi.org/10.1590/S1679-87592006000200002

MARGALEF, R., 1997. Turbulence and marine life. In MARRASÉ, C., SAIZ, E., REDONDO, JM., (Eds.). Lectures on plankton and turbulence. Scientia Marina, vol. 61, suppl. 1, p. 109-123.

MCLACHLAN, A. and BROWN, AC., 2006. The Ecology of Sandy Shores. Burlington: Academic Press. 373 p.

MOSER, GAO., GIANESELLA, SMF., BARRERA-ALBA, JJ., BÉRGAMO, AL., SALDANHA-CORRÊA, FMP., MIRANDA, LB. and HARARI, J., 2005. Instantaneous transport of salt, nutrients, suspended matter and chlorophyll-a in the tropical estuarine system of Santos. Brazilian Journal of Oceanography, vol. 53, p. 115-127.

MOSER, GAO., SIGAUD-KUTNER, TC., CATTENA, CO., GIANESELLA, SMF., BRAGA, E.DS., SCHINKE, KP. and AIDAR, E., 2004. Algal growth potencial as an index of eutrophication degree in coastal areas under sewage disposal influence. Aquatic Ecosystem Health and Management, vol. 7, no. 1, p. 115-126. http://dx.doi.org/10.1080/14634980490281443

MUYLAERT, K., SABBE, K. and VYVERMAN, W., 2009. Changes in phytoplankton diversity and community composition along the salinity gradient of the Schelde estuary (Belgium/The Netherlands). Estuarine, Coastal and Shelf Science, vol. 82, p. 335-340. http://dx.doi.org/10.1016/j.ecss.2009.01.024

NOGUEIRA, E. and FIGUEIRAS, JF., 2005. The microplankton succession in the Ria de Vigo revisited: species assemblages and the role of weather-induced, hydrodynamic variability. Journal of Marine Systems, vol. 54, p.139-155. http://dx.doi.org/10.1016/j. jmarsys.2004.07.009

PAERL, HW., PINCKNEY, JL., FEAR, JM. and PEIERLS, BL., 1998. Ecosystem responses to internal and watershed organic matter loading: consequences for hypoxia in the eutrophying Neuse River Estuary, North Carolina, USA. Marine Ecology Progress Series, vol. 166, p.17-25. http://dx.doi.org/10.3354/meps166017

PINCKNEY, J., PAERL, H., TESTER, P. and RICHARDSON, T., 2001. The role of nutrient loading and eutrophication in estuarine ecology. Environmental Health Perspectives, vol. 109, p. 699-706.

PITCHER, GC. and JOYCE, LB., 2009. Dinoflagellate cyst production on the southern Namaqua shelf of the Benguela upwelling system. Journal of Plankton Research, vol. 31, no. 8, p. 865-875. http://dx.doi.org/10.1093/plankt/fbp040 
ROCHELLE-NEWALL, EJ. and FISHER, TR., 2002. Production of chromophoric dissolved organic matter fluorescence in marine and estuarine environments: an investigation into the role of phytoplankton. Marine Chemistry, vol. 77, p. 7-21. http://dx.doi. org/10.1016/S0304-4203(01)00072-X

SAKSHAUG, E. and ANDRESEN, K., 1986. Effect of light regime upon growth rate and chemical composition of a clone of Skeletonema costatum from the Trondheimsfjord, Norway. Journal of Plankton Research, vol. 8, no 4, p. 619-637. http:// dx.doi.org/10.1093/plankt/8.4.619

SARNO, D., KOOISTRA, WHCF., MEDLIN, LK., PERCOPO, I. and ZINGONE, A., 2005. Diversity in the genus Skeletonema (Bacillariophyceae): II. An assessment of the taxonomy of S. costatum-like species, with the description of four new species. Journal of Phycology, vol. 41, p.151-176. http://dx.doi. org/10.1111/j.1529-8817.2005.04067.x

São Paulo (Estado). Departamento de Águas e Energia Elétrica - DAEE, 2009. Banco de dados pluviográficos do Estado de São Paulo. CD-ROM.

SCHAREK, R., TUPAS, LM. and KARL, DM., 1999. Diatom fluxes to the deep sea in the oligotrophic North Pacific gyre at station ALOHA. Marine Ecology Progress Series, vol. 182, p. 55-67. http://dx.doi.org/10.3354/meps 182055

SCHMIEGELOW, JMM., GIANESELLA, SMF., SIMONETTI, C., SALDANHA-CORREA, FMP., FEOLI, E., SANTOS, JAP., SANTOS, MP., RIBEIRO, RB. and SAMPAIO, AFP., 2008. Primary Producers In Santos Estuarine System. In NEVES, R., BARETTA, J. and MATEUS, M., (Eds.). Perspectives on Integrated Coastal Zone Management in South America. Lisboa: IST Press. p.161-174.

SHOAF, WT. and LIUM, BW., 1976. Improved extraction of chlorophyll $\mathrm{a}$ and $\mathrm{b}$ from algae using dimethyl sulfoxide. Limnology and Oceanography, vol. 21, p. 926-928. http://dx.doi. org/10.4319/lo.1976.21.6.0926

SOURNIA, A., CHRETIENNOT-DINET, MJ. and RICARD, M., 1991. Marine phytoplankton: how many species in the world? Journal of Plankton Research, vol. 13, no 5, p. 1093-1099. http:// dx.doi.org/10.1093/plankt/13.5.1093

STAEHR, PA., WAITE, AM. and MARKAGER, S., 2009. Effects of sewage on bio-optical properties and primary production of coastal systems. Hydrobiologia, vol. 620, no. 1, p. 191-205.

TAYLOR, FJR., FUKUYO, Y., LARSEN, J. and HALLEGRAEFF, GM., 2003. Taxonomy of harmful dinoflagellates. In HALLEGRAEFF, GM., ANDERSON, DM. and CEMBELLA,
AD., (Eds.). Manual on Harmful Marine Microalgae. Paris: Unesco Publishing. p. 389-482.

THOMAS, WH., HOLLIBAUGH, JT., SEIBERT, DLR. and WALLACE, GTJ., 1980. Toxicity of a Mixture of Ten Metals to Phytoplankton. Marine Ecology Progress Series, vol. 2, p. 213220. http://dx.doi.org/10.3354/meps002213

TENENBAUM, DR., VILLAC, MC., VIANA, SC., MATOS, M., HATHERLY, M., LIMA, IV. and MENEZES, M. 2004. Phytoplankton Atlas of Sepetiba Bay, Rio de Janeiro, Brazil. Londres: IMO. p. 132.

TOMAS, CR., 1997. Identifying marine phytoplankton. San Diego: Academic Press. 858 p.

UTERMÖHL, U., 1958. Perfeccionomiento del metodo cuantitativo de fitoplancton. Comunication of Association International of Theoretical and Applied Limnology Michigan, vol. 9, p. 1-89.

VILLAC, MC. and NORONHA, VADC., 2008. The surf-zone phytoplankton of the State of Sao Paulo, Brazil. I. Trends in spacetime distribution with emphasis on Asterionellopsis glacialis and Anaulus australis (Bacillariophyta). Nova Hedwigia, p. 115-129.

VILLAC, MC., NORONHA, VAPC. and PINTO, TO., 2008. The phytoplankton biodiversity of the coast of the state of São Paulo, Brazil. Biota Neotropica, vol. 8, no. 3, p. 151-173.

WALTER, H., CONSOLARO, F., GRAMATIC, P., SCHOLZE, M. and ALTENBURGER, R., 2002. Mixture toxicity of priority pollutants at no observed effect concentration. Ecotoxicology, vol. 11, p. 299-310. http://dx.doi.org/10.1023/A:1020592802989

WELSCHMEYER, NA., 1994. Fluorometric analysis of chlorophyll $\mathrm{a}$ in the presence of chlorophyll $\mathrm{b}$ and pheopigments. Limnology and Oceanography, vol. 39, p. 1985-1992. http://dx.doi.org/10.4319/ lo.1994.39.8.1985

WHITEA, DL., PORTERA, DE. and LEWITUSB, AJ., 2004. Anthropogenic Influences on the Ecology of Tidal Creeks and Canals: Spatial and temporal analyses of water quality and phytoplankton biomass in an urbanized versus a relatively pristine salt marsh estuary. Journal of Experimental Marine Biology and Ecology, vol. 298, no. 2, p. 255-273. http://dx.doi.org/10.1016/j. jembe.2003.07.001

ZAR, JH., 1999. Biostatistical Analysis. Prentice-Hall, Inc. 662 p.

ZINGONE, A. and ENEVOLDSEN, HO., 2000. The diversity of harmful algal blooms: a challenge for science and management. Ocean \& Coastal Management, vol. 43, p. 725-748. http://dx.doi. org/10.1016/S0964-5691(00)00056-9 
